\title{
Estrus Synchronization and Fixed Time Artificial Insemination (FTAI) in Dairy Buffaloes during Seasonal Anestrus
}

\author{
Luciana Ferri Frares ${ }^{1}$, Romildo Romualdo Weiss ${ }^{2}$, Luiz Ernandes Kozicki ${ }^{*}$, Renata \\ Prestes Santangelo ${ }^{1}$, Renata Azevedo de Abreu ${ }^{2}$, Ivo Walter do Santos ${ }^{4}$, José Antonio \\ Dell'aqua Junior ${ }^{5}$ and José Carlos Breda ${ }^{3}$ \\ ${ }^{1}$ Programa de Pós Graduação em Ciências Veterinárias; Universidade Federal do Paraná; Curitiba - PR - Brasil. \\ ${ }^{2}$ Programa de Pós Graduação em Processos Biotecnológicos, Universidade Federal do Paraná; Curitiba - PR - \\ Brasil. ${ }^{3}$ Escola de Ciências Agrárias e Medicina Veterinaria; Pontificia Universidade Católica do Paraná; ; \\ Curitiba - PR - Brasil. ${ }^{4}$ Medicina Veterinaria; Universidade Federal do Paraná; Campus de Palotina; Palotina - \\ PR - Brasil. ${ }^{5}$ Departamento de Reprodução Animal; Universidade Estadual Paulista; Campus de Botucatu; São \\ Paulo - SP - Brasil
}

\begin{abstract}
The aim of this work was to study estrus synchronization and fixed time artificial insemination (FTAI) in dairy buffaloes during season anestrus. One hundred thirty-nine dairy buffaloes in seasonal anestrus were divided in two groups as G1(n=66) and G2(n=73). The protocols for both the groups were the same until day (D)14:D0 administration of $2.0 \mathrm{mg}$ estradiol benzoate and implantation of progesterone device $\left(P_{4}\right)$ for 14 days; $D 14$ removal of $P_{4}$ plus $150 \mathrm{mg}$ of cloprostenol and $400 \mathrm{IU}$ of equine chorionic gonadotropin. On D16, G1 received $10 \mathrm{mg}$ of buserelin and G2 $100 \mathrm{mg}$ deslorelin acetate. On D17, both the groups were submitted to FTAI. Ultrasonographic examinations of ovaries were performed on D0, D14, D16 and D17. Results showed that pregnancy rates in G1 and G2 were 20 and $41 \%(p<0.05)$ and the ovulation rates were 16.6 and $37 \%$, respectively $(p<0.05)$. The dominant follicle (DF) diameter on D16 was $7.9 \mathrm{~mm}$ in G1 and $8.9 \mathrm{~mm}$ in G2 ( $p>0.05)$. Thirty-five percent of the animals in G1 and $54.1 \%$ in G2 showed a diameter DF greater than $8.0 \mathrm{~mm}$ on D16 ( $p>0.05)$. Thus, it could be concluded that the protocols synchronized the estrus, leading the concentration of the parturitions in the period of low milk production. Deslorelin was more efficient than buserelin due the higher percentage of DF ovulation and higher pregnancy rates.
\end{abstract}

Key words: Estrus Synchronization, Seasonal Anestrus, Dairy Buffaloes, Deslorelin, Buserelin, FTAI

\section{INTRODUCTION}

The buffalo herd plays an important role in the world's production of animal protein, especially in third world countries. It is estimated that this herd is increasing by $10 \%$ per year, reflecting the growing interest worldwide in this species (Vale 1988). The Brazilian population of Bubalus bubalis is estimated as 2.5 million animals and has shown an average annual growth of 12\% (Diaz et al. 2001). Hence, it is necessary to improve the quality and quantity in the production and reproduction of these animals.

The reproductive seasonality of the dairy buffalo is the physiological factor that exerts the greatest impact on this economic activity. The highest

\footnotetext{
*Author for correspondence: kozicki.1@pucpr.br
} 
concentration of parturitions in this species is seen from March to June in the Southern and Southeastern Brazil (mainly between parallels 24 and 26), and it determines the concentration of milk production until September, with a significant reduction, or even absence of milk in the summer months (Baruselli et al. 2003). In this region, poor buffalo farmers depend heavily on the milk production from the buffaloes. Thus, the development and implementation of reproductive biotechnologies, such as estrus synchronization associated to FTAI in this species, could be of significant relevance in this region. In places far from the equatorial region, the reduction in hours of light per day has a positive influence on the female buffaloes' reproductive behavior. There is evidence that high environmental temperatures, photoperiod, relative humidity, and high levels of rainfall influence the reproductive endocrine system (Shah et al. 1990; Zicarelli et al. 1990). Due to this seasonality, the concentration of parturition results in a reduction in the milk production.

One of the limiting factors in the application of artificial insemination (AI) in buffaloes is the difficulty in the estrus detection. A small number of females exhibit homosexual behavior, the signs of estrus are discrete, and it occurs mainly at night. Therefore, the use of hormonal protocols associated with FTAI makes reproduction in these animals more advantageous and practical, especially during the seasonal anestrus (Baruselli and Carvalho 2005).

Methods for the detection of estrus have been developed to facilitate the management of reproductive programs and to increase the efficiency of AI protocols. These protocols synchronize follicular growth and ovulation, allowing the performance of FTAI. Many female buffaloes present prolonged periods of anestrus during the unfavorable breeding season (spring/ summer) and do not respond properly to the treatment with only the Ovsynch protocol. Protocols using $\mathrm{P}_{4}$, estradiol, prostaglandin, $\mathrm{GnRH}$, and eCG improve the pregnancy rates in female buffaloes (Baruselli et al. 2003). The use of deslorelin acetate (a GnRH agonist) has been reported in the dogs (Trigg et al. 2006), cattle (Bergfeld et al. 1996; Ambrose et al. 1998; Ramajahendran et al. 1998; Bartolome et al. 2004; Padula and Macmillan 2005; Silvestre et al. 2009), horses (Mckinnon et al. 1993; Squires et al. 1994; Mumford et al. 1995; Vanderwall et al. 2001;
Melo et al. 2005; Raz et al. 2009; Lindholm et al. 2010) and sheep (Schneider and Rehbock 2003).

There are no reports on the use of deslorelin acetate in female buffaloes for estrus synchronization and ovulation. The use of deslorelin acetate in the female buffaloes has only been reported in the protocols used for ovary superovulation, involved in embryo transfer procedures. This agonist induces ovulation in fertile buffaloes and the recovery rate of embryos is reported at about 46\% (Carvalho et al. 2002).

This study aimed at the synchronization of estrus in dairy buffaloes during the period of seasonal anestrus using hormonal protocols associated with different inductors of ovulation and FTAI in order to concentrate the parturitions in the period of low milk production in the buffalo herd from Southern Brazil.

\section{MATERIALS AND METHODS}

\section{Animals}

The experiment was carried out between September/October until January 2010, which corresponded to the yearly period of seasonal anestrus (absence of estrus, ovulation and pregnancy) in Bubalus bubalis in Southern Brazil. The breeding season extends from March to June (parturitions and estrus after puerperium period, determining the concentration of milk production until September). None of the buffaloes showed the signs of estrus during the protocol (before, or after buserelin/deslorelin). One hundred thirty-nine pluriparous Murrah female buffaloes showing body condition scores of 3.5 (in a 1-5 scale, Edmondson et al. 1989) from three dairy farms were used. The animals were maintained on pasture (Brachiaria decumbens) and mineral supplements were given ad libitum in troughs. The daily mechanical milking in the presence of calves was performed in the mornings and the average milk production per animal was 10 liters.

\section{Experimental Design}

The animals were divided in two groups $(\mathrm{G})$ : G1 $(n=66)$ and G2 (n=73). On D0, the buffaloes (both groups) received $2.0 \mathrm{mg}$ of estradiol benzoate (EB) (Cronibest ${ }^{\circledR}$, Biogenesis-Bago, Brazil) IM and were implanted with an intravaginal progesterone device $\left(\mathrm{P}_{4}\right)$ (Cronipres monodose ${ }^{\circledR}$, Biogenesis-Bago, Brazil), which remained implanted for 14 days (Sing 2003). On D14, $150 \mathrm{~g}$ 
of D-cloprostenol (Croniben $®$, Biogenesis-Bago, Brazil) and 400 IU of equine chorionic gonadotropin - eCG (Folligon ®, Intervet Schering-Plough Animal Health, Brazil) were administered to both the groups (IM) and the $\mathrm{P}_{4}$ was removed from every animal. On D16, the G1 animals received $10 \mathrm{mg}$ of buserelin acetate IM (Conceptal ${ }^{\circledR}$, Intervet Schering-Plough Animal Health, Brazil) and the G2 animals received 100 $\mathrm{mg}$ of deslorelin acetate IM. The FTAI occurred on D17 as presented in Figures 1 and 2.

\begin{tabular}{|c|c|c|c|}
\hline $2 \mathrm{mg} \mathrm{EB}$ & Removal P4 + & $10 \mathrm{mg}$ & FTAI \\
\hline$+\mathrm{P} 4$ & $150 \mathrm{mcg}$ PG $+400 \mathrm{UI}$ eCG & buserelin & \\
\hline$\uparrow$ & $\uparrow$ & $\uparrow$ & $\uparrow$ \\
\hline D0 & D14 & D16 & D17 \\
\hline
\end{tabular}

Figure 1 - Hormonal protocol in group 1 of buffaloes aiming at the FTAI in seasonal anestrus.

\begin{tabular}{|llll|}
\hline $2 \mathrm{mg} \mathrm{EB}$ & Removal P4+ & $100 \mathrm{mg}$ & FTAI \\
$+\mathrm{P} 4$ & $150 \mathrm{mcg}$ PG $+400 \mathrm{UI} \mathrm{eCG}$ & deslorelin & \\
\hline $\mathrm{D} 0$ & $\mathbf{D} 14$ & $\mathrm{D} 16$ & $\mathrm{P} 17$ \\
\hline
\end{tabular}

Figure 2 - Hormonal protocol in group 2 of buffaloes aiming at the FTAI in seasonal anestrus.

$\mathrm{EB}=$ estradiol benzoate; $\mathrm{P} 4=$ progesterone; $\mathrm{PG}=$ prostaglandin $\mathrm{F} 2 \alpha$; eCG=equine chorionic gonadotropin.

\section{Ultrasonography}

Ultrasonographic examinations (U.S.) $(5 \mathrm{MHz}$ linear transducer - Aloka model 500) of the ovaries were performed in all the animals to assess the ovarian activity before the start of the hormonal protocols. The examinations were performed on D0, D14, D16, and D17. The examination on D16 was performed to verify the presence of DF presenting diameters greater than $8.0 \mathrm{~mm}$ (Fig. 3) and on D17 (day of FTAI) to verify the occurrence of ovulation. Thus, the ultrasonography results on D17 showing the absence of DF, previously detected on D16, was considered as an indicator of ovulation (Nasser et al. 1993). Synchronization of ovulation was considered present when occurred within $24 \mathrm{~h}$ after the application of buserelin, or deslorelin acetate. Pregnancy diagnosis was performed 55 days after AI via ultrasonography.

\section{Statistical Analyses}

Ovulation rate, pregnancy rate after FTAI, the percentage of animals with follicles greater than 8 $\mathrm{mm}$ in diameter, and the percentage of pregnancy with follicles greater than $8 \mathrm{~mm}$ in diameter were analyzed using the Chi-Square test. The diameter of the DF was analyzed with the Student's t test. In both the tests, differences with $\mathrm{p}<0.05$ were considered significant.

\section{RESULTS AND DISCUSSION}

The $\mathrm{P}_{4}$ protocol, applied in this study was based on a study on buffaloes during an unfavorable reproductive season (Sing 2003). In that study, the author suggested that the treatment with $\mathrm{P}_{4}$ was more effective when the implants remained for 10 to 14 days compared to eight days only. The use of $400 \mathrm{IU}$ of eCG, at the time of the $\mathrm{P}_{4}$ removal, increased the ovulation and conception rates in the buffaloes without $\mathrm{CL}$ at the time of the $\mathrm{P}_{4}$ implantation (Baruselli et al. 2002). In the present study (Table 1), the pregnancy rate in $37 \%$ of the animals submitted to hormonal protocols for synchronization of estrus and induction of ovulation followed by FTAI was observed. This rate would not be possible without the administration of hormonal protocols because the animals were in seasonal anestrus, outside of the reproductive season, thus demonstrating the importance of present study. The $37 \%$ pregnancy rate resulted in the concentration of parturitions and subsequently in improved milk production in 
the period when milk availability was beneficial for the small local producers. G2 (deslorelin acetate) showed better rates than G1 (buserelin acetate), not only for the ovulation but also for the pregnancy $(\mathrm{p}<0.05)$.

Table 1 - Ovulation (D17) and pregnancy rates after the FTAI in Murrah breed dairy buffaloes during seasonal anestrus $(\%) .(\mathrm{n}=139)$.

\begin{tabular}{llll} 
& G1(buserelin) & G2 (deslorelin) & Total \\
\hline Ovulation rate & $11 / 66(16.6)^{\mathrm{a}}$ & $27 / 73(37.0)^{\mathrm{b}}$ & \\
$\begin{array}{l}\text { Pregnancy rate } \\
\text { Total pregnancy rate }\end{array}$ & $13 / 66(20.0)^{\mathrm{a}}$ & $30 / 73(41.0)^{\mathrm{b}}$ & 37.0 \\
\hline
\end{tabular}

Different letters in the same row indicate significant difference $(\mathrm{p}<0.05)$.

There are currently no reports on the effects of deslorelin in inducing the ovulation in estrus synchronization and FTAI protocols in female buffaloes. Thus, the present work is first report on this. The results from this study showed smaller percentage rates than the rates reported by Presicce et al. (2005). However, these authors applied the $\mathrm{P}_{4}$ protocol added by the administration of eCG or the Ovsynch protocol in the animals that were cycling (40.9\%). Other studies demonstrated that when the Ovsynch protocol was used in female buffaloes during the unfavorable reproductive season (seasonal anestrus), the conception rates were quite variable: $28.2 \%$ (Baruselli et al. 2002); 6.9\% (Baruselli et al. 2003); 34\% (Campanile et al. 2005); 30\% (Warriach et al. 2008). In the present study, deslorelin acetate was used to induce the ovulation ( $\mathrm{GnRH}$ agonist), which resulted in conception rates $(39.6 \%)$ higher than the rates reported in other studies using the Ovsynch protocol, indicating that deslorelin acetate was more efficient in female buffaloes under these conditions.

The pre-ovulatory follicle (Fig. 3) was the largest follicle at pro-estrus and estrus (El-Wishy and Ghoneim 1995) and presented constant growth (Marion et al. 1968). In this study, the DF presented an average diameter of $7.9 \mathrm{~mm}$ in G1 (buserelin) and $8.9 \mathrm{~mm}$ in G2 (deslorelin) (Table 2). These results were similar to an average diameter of $9.0 \mathrm{~mm}$ for the DF reported in the literature (Berber et al. 2002). Rastegarnia et al. (2004) observed the DF average diameter as 12.7 $\mathrm{mm}$ in the experiments using synchronized ovulation and comparing different doses of gonadorelin in female buffaloes in the season breeding. This DF average value was higher than the values observed in the present study, which was performed outside the favorable reproductive season.

It has reported that the DF in female buffaloes could ovulate when the diameter was around 5-8 mm (Baruselli et al. 1997), which corroborated the results observed in this study with the DF diameters reaching averages between 7.9 and 8.9 $\mathrm{mm}$. These results were also similar to results previously reported (Campanile et al. 2007; Campanile et al. 2008) of follicles with diameters from 4.2 to $13.0 \mathrm{~mm}$, when ovulation was induced with hCG ,or GnRH agonist. On D16, $48.5 \%$ of the animals presented DF in both the groups, indicating that the protocols used for estrus synchronization showed satisfactory efficiency rates. These results were promising compared to previously reported results about synchronized estrus in cyclic and acyclic pluriparous female buffaloes during a favorable reproductive season and using the Ovsynch protocol, or $\mathrm{P}_{4}$ added by the administration of eCG (Presicce et al. 2005).

Table 2 - Parameters of the DF diameter ( $\mathrm{mm})$, percentage of animals with follicle greater than 8 mm in diameter, and pregnancy rate with follicles greater than $8 \mathrm{~mm}$ in diameter observed on D16 in Murrah breed dairy buffaloes during the seasonal anestrus (\%). $(\mathrm{n}=139)$.

\begin{tabular}{lll}
\hline Parameter (D16) & G1 (buserelin) & G2 (deslorelin) \\
\hline Animals (n) & 66 & 73 \\
DF (diameter x $\pm \mathrm{s}$ ) & $7.9 \pm 0,7^{\mathrm{a}}$ & $8.9 \pm 0.4^{\mathrm{a}}$ \\
DF (larger diameter, $\mathrm{x} \pm \mathrm{s}$ ) & 15.0 & 20.0 \\
DF (smaller diameter, $\mathrm{x} \pm \mathrm{s})$ & 4.0 & 2.0 \\
Ovaries with follicles $>8 \mathrm{~mm}(\%)$ & $35.0^{\mathrm{a}}(7 / 20)$ & $54.1^{\mathrm{a}}(26 / 48)$ \\
Pregnancy with follicles $>8 \mathrm{~mm}(\%)$ & $50.0^{\mathrm{a}}$ & $63.1^{\mathrm{a}}$ \\
\hline
\end{tabular}




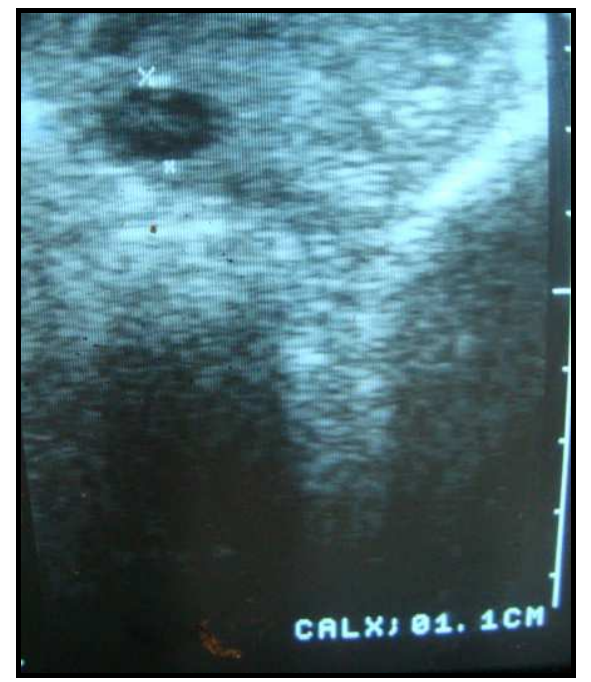

Figure 3 - Dominant follicle showing $11.0 \mathrm{~mm}$ in diameter, detected by ultrasound examination on D16 in animals submitted to the protocol using deslorelin.

\section{CONCLUSION}

The hormonal protocols used in this study showed satisfactory efficiency in order to estrus synchronization and pregnancy rate. The application of the both the protocols allowed the concentration of parturitions during the period of low, or absent production of milk, which represented an important business improvement for the small local milk producers. The protocol using deslorelin acetate was more effective than the protocol using buserelin acetate; the deslorelin protocol provided greater percentage of DF ovulation and higher pregnancy rates.

\section{REFERENCES}

Ambrose JD, Pires MFA, Moreira F, Diaz T, Binelli M, Thatcher WW. Influence of deslorelin (GnRHagonist) implant on plasma progesterone, first wave dominant follicle and pregnancy in dairy cattle. Theriogenology. 1998; 50:1157-1170.

Bartolome JA, Santos JEP, Pancarci SM, Melendez P, Arteche ACM, Hernandez $\mathrm{O}$, et al. Induction of ovulation in nonlactating dairy cows and heifers using different doses of a deslorelin implant. Theriogenology, 2004; 61: 407-419.

Baruselli PS, Carvalho NAT, Henriquez CHP, Amaral R. Synchronization of ovulation for timed artificial insemination during the of breeding season in the buffalo. In: Buffalo Symposium of Americas, 1st 2002, Belém. Proceedings: Belém: Embrapa/CPATU. 2002; 1: 418-420.
Baruselli PS, Carvalho NAT. Biotechnology of reproduction in buffalo (Bubalus bubalis). Rev Bras Reprod Anim. 2005; 29: 4-17.

Baruselli PS, Madureira EH, Barnarbe VH, Barnabe RC, Berber RCA. Evaluation of synchronization of ovulation for fixed timed insemination in buffalo (Bubalus bubalis), Braz J Vet Res Anim Sci. 2003; 40:431-442.

Baruselli PS, Mucciolo RG, Visintin JA, Viana WG, Arruda RP, Madureira EH, et al. Ovarian follicular dynamics during the estrous cycle in buffalo (Bubalus bubalis). Theriogenology. 1997; 47:1531-1547.

Berber RCA, Madureira E.H, Baruselli PS. Comparison of two Ovsynch protocols (GnRH versus LH) for fixed timed insemination in buffalo (Bubalus bubalis). Theriogenology. 2002; 57:1421-1430.

Bergfeld EG, D'Occhio MJ, Kinder JE. Pituitary function, ovarian follicular growth, and plasma concentrations of 17 beta-estradiol and progesterone in prepubertal heifers during and after treatment with the luteinizing hormone-releasing hormone agonist deslorelin. Biol Reprod. 1996; 54:776-782.

Campanile G, DI Palo R, Neglia G, Vecchio D, Gasparrini B, Prandi A, et al. Corpus luteum function and embryonic mortality in buffaloes treated with a GnRH agonist, hCG andprogesterone. Theriogenology. 2007; 67:1393-1398.

Campanile G, Neglia G, Gasparrini B, Galiero G, Prandi A, Di Palo R, et al. Embryonic mortality in buffaloes synchronized and mated by AI during the seasonal decline in reproductive function. Theriogenology. 2005; 63:2334-2340.

Campanile G, Vecchio D, Neglia G, Di Palo R, Prandi A. D’Occhio M.J. Progesterone and pregnancy status in buffaloes treated with a GnRH agonist. Livest Sci. 2008; 115: 242-248. 
Carvalho NAT, Baruselli PS, Zicarelli L, Madureira EH, Visintin JA, D'Occhio MJ. Control of ovulation with a GnRH agonist after superstimulation of follicular growth in buffalo: fertilization and embryo recovery. Theriogenology. 2002; 58:1641-1650.

Diaz JDS, Oliveira ATD, Aguiar PRL, Rodrigues JL. Ultrasonographic diagnosis of ovulation time in buffaloes (Bubalus bubalis) inseminated at spontaneous and induced estrus. Cien Rural. 2001; 31:657-662.

Edmondson AJ, Lean IJ, Weaver LD, Farver T, Webster, G. A body condition scoring chart for Holstein dairy cows. J Dairy Sci. 1989; 72: 68-78.

El-Wishy AB, Ghoneim IM. Ovarian function in buffalo cows with special reference to the accuracy of rectal palpation. Reprod Dom Anim. 1995; 30: 39-41.

Lindholm ARG, Bloemen EHG, Brooks RM, Ferris RA, Mccue PM. Comparison of deslorelin and buserelin in mares: $\mathrm{LH}$ response and induction of ovulation. Anim Reprod Sci. 2010; 121:68-70.

Marion GB, Gier MT, Choudary JB. Micromorphology of the bovine ovarian follicular system. J Anim Sci. 1968; 27: 451-465.

Mckinnon AO, Nobellius AM, Tarrida DEL, Marmo L, Figueroa S, Skidmore V, et al. Predictable ovulation in mares treated with an implant of the GnRH analogue deslorelin. Eq Vet J. 1993; 25:321-323.

Melo CM, Papa FO, Medeiros ASL, Dell'aqua JR JA, Carmo MT, Araújo GM, et al. Effect of deslorelin and equine pituitary extract to induce ovulation in mares. In: XIX Annual Meeting of SBTE, 2005, Acta Sci Vet. 2005; 33: 193.

Mumford EL, Squires EL, Jöchle E, Harrison LA, Nett TM, Trigg TE. Use of deslorelin short-term implants to induce ovulation in cycling mares during three consecutive estrous cycles. Anim Reprod Sci. 1995; 39:129-140.

Nasser LF, Adams GP, Bo G, Mapletoft RJ. Ovarian superovulatoy response relative to follicular wave emergence in heifers. Theriogenology. 1993; 40:713724.

Padula AM, Macmillan KL. Observations on the reproductive effects of once or twice weekly injections for 6 weeks of the GnRH agonist deslorelin in the cow. Anim Reprod Sci. 2005; 85:223-230.

Presicce GA, Senatore EM, De Santis G, Bella A. Follicle turnover and pregnancy rate following estrus synchronization protocols in Mediterranean Italian buffaloes (Bubalus bubalis). Reprod Domest Anim. 2005; 40: 443-447.

Rajamahendran R, Ambrose JD, Schmitt EJ, Thatcher MJ, Thatcher WW. Effects of buserelin injection and deslorelin (GnRH-agonist) implants on plasma progesterone, $\mathrm{LH}$, accessory $\mathrm{CL}$ formation, follicle and corpus luteum dynamics in Holstein cows. Theriogenology. 1998; 50: 141-1155.
Rastegarnia A, Niasari-Naslaji A, HovareshtI P, Sarhaddi F, Safaei M. The effect of different doses of Gonadorelin on ovarian follicle dynamics in river buffalo (Bubalus bubalis). Theriogenology. 2004; 62:1283-1291.

Raz T, Carley S, Card C. Comparison of the effects of eFSH and deslorelin treatment regimes on ovarian stimulation and embryo production of donor mares in early vernal transition. Theriogenology. 2009; 71:1358-1366.

Schneider F, Rehbock F. Induction of fertile cycles in the Blackhead sheep during the anoestrus period. Arch Anim Breed. 2003; 46:47-61.

Shah NH, Willemse AH, Van De Weil DFM. Descriptive epidemiology and treatment of postpartum anestrus in dairy buffalo under small farm conditions. Theriogenology. 1990; 33:1333-1345.

Silvestre FT, Kamimura S, Arteche AC, Bartolome J, Pancarci SM, Thatcher WW. Reproductive responses following postpartum suppression of ovarian follicular development with a deslorelin implant during summer heat stress in lactating dairy cows. Anim Reprod Sci. 2009; 111: 320-337.

Sing C. Response of anestrus rural buffaloes (Bubalus bubalis) to intravaginal progesterone implants and PGF2alpha injection in summer. J Vet Sci. 2003; 4: 137-141.

Squires EL, Moran DM, Farlin ME, Jasko DJ, Keefe TJ, Meyers SA, et al. Effect of dose of GnRH analog on ovulation in mares. Theriogenology. 1994; 41:757769.

Trigg TE, Doyle AG, Walsh JD, Swangchan-Uthai T. A review of advances in the use of the GnRH agonist deslorelin in control of reproduction. Theriogenology. 2006; 66:1507-1512.

Vale WG. Buffaloes: Physiology and Pathology of Reproduction. Campinas, Cargill Foundation, 1988; 86.

Vanderwall DK, Juergens TD, Woods GL. Reproductive performance of commercial broodmares after induction of ovulation with hCG or Ovuplant $^{\mathrm{TM}}$ (deslorelin). J Eq Vet Sci. 2001; 21:539542.

Warriach HM, Channa AA, Ahmad N. Effect of oestrus synchronization methods on oestrus behaviour, timing of ovulation and pregnancy rate during the breeding and low breeding seasons in Nili-Ravi buffaloes. Anim Reprod Sci. 2008; 107: 62-67.

Zicarelli L, Francillo M, Pacelli C, Villa EE. Influence of insemination technique and ovulation time on fertility percentage in synchronized buffaloes. In: Proceedings: The World Buffalo Congress. 1990; 5:732-737. 